\title{
Akcijske filmske junakinje na početku novog tisućljeća
}

Irena Sever Globan*

irena.sever@unicath.hr

Ana Kralj**

ana_kralj92@yahoo.com https://doi.org/10.31192/np.17.1.1

UDK: 305-055.2:791.221.7

791.221.7:305-055.2

Izvorni znanstveni rad / Original scientific paper Primljeno: 3. srpnja 2018. Prihvaćeno: 7. prosinca 2018.

Suvremeni mediji su jedan od čimbenika koji sudjeluju u oblikovanju osobnog $i$ društvenog identiteta, kao $i$ vrijednosti na globalnoj razini, čemu pripada $i$ definiranje i oblikovanje rodnih uloga. One se u medijima najčešće prikazuju kroz razne stereotipe, s time da se tradicionalno muške osobine češće naglašavaju kao vrjednije, dok je žena u medijima (posebno onima fikcijskog karaktera) svedena na objekt muške žudnje. Članak stoga pokušava otkriti je li u posljednjem desetljeću došlo do kakvih promjena s obzirom na (ne)stereotipan prikaz filmskih junaka i junakinja akcijskog žanra u holivudskim uspješnicama. Iz tog je razloga metodom analize sadržaja analizirano 86 glavnih $i$ većih sporednih likova u deset najgledanijih filmova prema »Yearly Box Office« izmedu 2007. $i$ 2016. godine te je zaključeno da su rodni stereotipi i dalje prisutni u akcijskim filmskim uspješnicama, posebno s obzirom na premalu prisutnost ženskih glavnih likova te erotizaciju i objektivizaciju ženskog tijela.

Ključne riječi: mediji, rodne uloge, stereotipi, akcijski film, filmski junaci.

\footnotetext{
* Doc. dr. sc. Irena Sever Globan, Odjel za komunikologiju, Hrvatsko katoličko sveučilište, Ilica 242, HR-10000 Zagreb.

**Ana Kralj, mag. comm., suradnica na RTL televiziji, Krapinska 45, HR-10000 Zagreb.
} 


\section{Uvod}

Ženstvenost i muževnost imaju vremensku i prostornu karakteristiku ovise o kulturi i vremenu u kojem živimo, a uz ostale socijalizacijske elemente mediji, pa tako i film, imaju važnu ulogu u oblikovanju identiteta i stvaranju društvene slike. ${ }^{1}$ Masovne medije stoga možemo definirati kao suvremenu arenu u kojoj se odigravaju važne »bitke« i pregovori o značenju i rodnim ulogama²; oni su moćna institucija socijalizacije uz pomoć kojih gradimo naš osobni i društveni identitet. Glazbene i filmske zvijezde, takozvani influenceri i trendseteri te razne celebrity ličnosti, kao medijski protagonisti (odnosno kao prezentna lica industrije masovnih medija), ponuđeni su uzori s kojima će se mnogi uspoređivati i kojima će težiti postati slični. Oni odražavaju društvenokulturne stvarnosti i promjene, nude modele za imitiranje i oblikuju ideje o tome što znači biti muško i žensko, kako bi idealna žena i muškarac trebali izgledati, ponašati se i govoriti. Na taj način sudjeluju u socijalizaciji i edukaciji $»$ koristeći društvene i spolne uzore «. ${ }^{3}$

Percipiranje žene i njene uloge u društvu ovisi dakle i o njenoj prezentaciji u medijima te stoga način na koji mediji prikazuju žene, ali i muškarce, za gledatelje neće biti neutralno, i to posebno za one najranjivije - djecu i mlade. Povjesničar umjetnosti Erwin Panofsky u tom smislu tvrdi da su vizualni prikazi žena kulturalni simptomi čija analiza može pomoći u identificiranju glavnih tendencija u pogledu položaja žena neke kulturne ere. ${ }^{4}$

Isticanje stereotipnih razlika glavni je način na koji mediji kao prenositelji javnog mnijenja obrađuju seksualnost i rodne uloge, ${ }^{5}$ a koje općenito mogu biti stereotipne, neutralne i kontrastereotipne tradicionalnim rodnim ulogama. ${ }^{6}$ Kroz povijest su se oblikovali i učvrstili mnogi rodni stereotipi. Rezultati

${ }^{1}$ Usp. Z. PENEZIĆ, M. ŠUNJIĆ, Mediji, ženska rodna uloga i rodni stereotipi, Kultura komuniciranja, 2 (2013) 2, 77-92, 77-78.

${ }^{2} \mathrm{U}$ članku ne koristimo termine »rod « $\mathrm{i} » s p o l «$ kao istoznačnice. Pod terminom »spol « podrazumijevamo razlikovne osobine koje su biološki i nasljedno uvjetovane, a pod terminom »rod « pak one uvjetovane odgojem i društvenom okolinom: »Ljudi se rađaju kao muško i žensko, ali uče da budu dječaci i djevojčice koji će odrastati i postati muškarci i žene. To naučeno ponašanje čini rodni identitet i uvjetuje rodne uloge«. J. R. ANIĆ, Kako razumjeti rod? Povijest rasprave i različita razumijevanja u Crkvi, Zagreb, Institut društvenih znanosti Ivo Pilar, 2011, 23. Usp. A. HODŽIĆ, N. BIJELIĆ, S. CESAR, Spol i rod pod povećalom. Priručnik o identitetima, seksualnosti i procesu socijalizacije, Zagreb, Cesi, 2003. Iz tog ćemo razloga koristiti pojmove »rodni identitet«, »rodni stereotipi«, »rodne uloge« kada je riječ o društveno-odgojnim uvjetovanostima, te »muški spol« $\mathrm{i}$ »ženski spol « kada je riječ o biološim zadanostima.

${ }^{3}$ D. DAMEAN, Constructing Feminine Identities in a Postmodern World, Journal for the Study of Religions and Ideologies, 5 (2006) 14, 89-94, 90.

${ }^{4}$ Usp. E. PANOFSKY, Meaning in the Visual Arts, Chicago, The University of Chicago Press, 1955.

${ }^{5}$ Usp. D. KUKIĆ, D. JURČIĆ, Žene u medijima. Podjela društvene (ne)moći, Kultura komuniciranja, 2 (2013) 2, 60-76, 61.

${ }^{6}$ Usp. K. DURKIN, Television and Sex-Role Acquisition: 1. Content, British Journal of Social Psychology, 24 (1985) 2, 101-113. 
međukulturalnog istraživanja kojeg su 1990. godine proveli Williams i Best u trideset i dvije zemlje, jasno pokazuju da se muškarce doživljava kao nezavisne, dominantne, neemocionalne, maskuline, pustolovne, agresivne, hrabre, poduzetne, moćne, nepristojne, ozbiljne i mudre, a žene kao submisivne, praznovjerne, sentimentalne, feminine, sanjalačke, nježne, osjetljive, slabe, mekog srca, emocionalne, plašljive, ovisne, atraktivne i seksi. ${ }^{7}$ Problem je što rodni stereotipi ne ocrtavaju samo kakvi muškarci i žene jesu već i što se od njih očekuje da budu. Ljudi naime imaju tendenciju da se ponašaju u skladu s društvenim normama i očekivanjima pa tako, u nekim situacijama, mogu reproducirati stereotipe, iako im takvo ponašanje inače ne bi bilo prirodno. Odnosno, ono što se u literaturi naziva "prijetnja stereotipom " odnosi se i na uklapanje raširenih rodnih stereotipa u stvaranje vlastitog identiteta. ${ }^{8} \mathrm{I}$ bez obzira na težnje modernih zapadnih društava k rodnoj ravnopravnosti i emancipaciji žena, čini se da većina društava i dalje muški spol ističe kao superiorniji, a muške osobine vrednuje pozitivnije od onih tipično ženskih. ${ }^{9}$

Feministička medijska teorija velik problem vidi upravo u održavanju stereotipizacije, trivijalizacije i marginalizacije jednog od spolova, bilo u samom sadržaju, bilo u njegovoj proizvodnji. ${ }^{10}$ Stoga se ona zauzima za to da se stereotipizirana muško-ženska paradigma promijeni zbog negativne slike žena koje se nude muškarcima kao idealne, ali i zbog negativne samopercepcije koju one stvaraju kod samih žena. ${ }^{11}$ Slavica Juka i Ivana Primorac Bilaver sagledale su antropološki i medijski prikaz žene te došle do zaključka da se konzervativnost i patrijarhalnost društva najlakše uočavaju upravo iz iskrivljenog prikaza ženskih karakteristika - izvještavanje o njima je jednoznačno, monotono, dosadno i siromašno, a sve što se ne poklapa s dominantnom slikom ignorira se ili negira. ${ }^{12}$ Djeca i mladi koji su više izloženi medijima koji prikazuju rodne stereotipe, te ih prepoznaju kao takve, imaju slična rodna očekivanja kako od sebe tako i od drugih. ${ }^{13}$ Filmski junaci mogu ohrabriti mlade ljude da suženo gledaju na svijet s obzirom na uloge i mogućnosti koje im se pružaju:

\footnotetext{
${ }^{7}$ Usp. J. E. WILLIAMS, D. L. BEST, Measuring Sex Stereotypes. A Multination Study, Beverly Hills, Sage, 1990.

${ }^{8}$ Usp. Penezić, Šunjić, Mediji, ženska rodna uloga i rodni stereotipi..., 79-81.

9 Usp. J. MCKEE, A. C. SHERIFFS, The Differential Evaluation of Males and Females, Journal of Personality, 25 (1957) 3, 356-371; D. L. BEST, Gender Stereotypes, u: C. R. EMBER, M. EMBER (ur.), Encyclopedia of Sex and Gender. Men and Women in the World's Cultures, New York, Kluwer Academic - Plenum Publishers, 2003, 11-23.

${ }^{10}$ Usp. D. LABAŠ, M. MIHOVILOVIĆ, Masovni mediji i semiotika popularne kulture, Kroatologija, 2 (2011) 1, 95-121, 99-100.

${ }^{11}$ Usp. B. Hooks, Feminism is for Everybody. Passionate Politics, London, Pluto Press, 2000.

${ }^{12}$ Usp. S. JUKA, I. PRIMORAC BILAVER, Identitet žene - antropološka i medijska slika, Kultura komuniciranja, 2 (2013) 2, 11-31, 24-25.

${ }^{13}$ Usp. S. L. SMITH i dr., Assessing Gender-Related Portrayals in Top-Grossing G-Rated Films, Sex Roles, 62 (2010) 11, 774-786; E. D. ENGLAND, L. DESCARTES, M. A. COLLIER-MEEK, Gender Role Portrayal and the Disney Princesses, Sex Roles, 64 (2011) 555-567.
} 
»Za djevojke, nedostatak zastupljenosti može utjecati na njihov doživljaj važnosti ili samopoštovanja. Za dječake, takva izloženost može suptilno produžiti status quo i pojačati hegemonijski prikaz djevojaka i žena. ${ }^{14}$

No kada su osobe izložene netradicionalnom prikazu roda u medijima, puno spremnije prihvaćaju manje ograničavajuće poimanje rodnih normi i uloga. ${ }^{15}$ Naša percepcija i shvaćanje roda događa se tako kroz promatranje muških i ženskih modela, ${ }^{16}$ a filmovi takve modele nude kroz svoje likove i scenarije koji onda utječu na naše viđenje i očekivanja od žena i muškaraca.

I recentna studija iz 2017. američke neprofitne organizacije Common Sense Media pod nazivom Watching Gender: How Stereotypes in Movies and on $T V$ Impact Kids' Development, ${ }^{17}$ koja se temelji na opsežnoj analizi istraživanja o dječjem razvoju, rodu i medijima provedenih tijekom zadnjih 40 godina, pokazuje da mediji jačaju ideju da su muške osobine i ponašanja vrjednija od onih ženskih te da djevojke trebaju brinuti o svom izgledu i svoje tijelo tretirati kao seksualni objekt. ${ }^{18} \mathrm{U}$ adolescenciji je korištenje medija povezano s tolerantnijim stavovima prema seksualnom uznemiravanju i češćim uvjerenjem da su žene barem djelomično odgovorne ako dožive seksualno nasilje. Češće gledanje sadržaja s tradicionalno prikazanim rodnim ulogama povezano je s dječjim rodno tipiziranim težnjama u karijeri i čvršćim uvjerenjima o tome što muškarci i žene rade i jesu te kako se ponašaju. Mnogi stoga žude za kompleksnijim i nestereotipiziranim likovima, pogotovo kada je riječ o djevojkama i ženama, pa Morgan i Shipman zaključuju: »Vrijeme je da kreatori sadržaja

\footnotetext{
${ }^{14}$ Smith i dr., Assessing Gender-Related Portrayals in Top-Grossing G-Rated Films..., 783.

${ }^{15}$ Usp. Durkin, Television and Sex-Role Acquisition..., 101-113.

${ }^{16}$ Usp. A. BANDURA, R. H. WALTERS, Aggression in Child Psychology. The Sixty-Second Yearbook of the National Society for the Study of Education. Part I, Chicago, The National Society for the Study of Education, 1963.

${ }^{17}$ Usp. L. M. WARD, J. S. AUBREY (ur.), Watching Gender. How Stereotypes in Movies and on TV Impact Kids' Development, San Francisco, Common Sense, 2017.

${ }^{18}$ Čest je slučaj upiranja prstom u film i filmske uzore kada se govori o nezadovoljstvu vlastitim odrazom u ogledalu. Brojni su autori pisali o toj temi, a kao posljedice najčešće navode poremećaje u prehrani te opasnost za vlastito zdravlje. Tako su Shafer i suradnici razvili model (MPM - Media Practice Model) pomoću kojeg opisuju utjecaj masovnih medija, posebice filma, na seksualnost i poglede na ljubav i intimnost, seksualnu orijentaciju te brak, i to najviše kod mladih. Utjecaj se, prema autorima, prenosi takozvanim »seksualnim skriptima«. Njihov učinak neće uvijek biti jednak pa on tako ovisi i o pažnji koja se posvećuje sadržaju, uzbuđenju, emocionalnoj angažiranosti oko likova i svijeta u koji nas priča uvodi, čvrstoći karaktera i prijašnjih stavova i normi, očekivanja od samog sadržaja i otvorenosti kasnijem iskušavanju novih stvari te samopouzdanju (usp. A. S. SHAFER, P. S. BOBKOWSKI, J. D. BROWN, Sexual Media Practice. How Adolescents Select, Engage with, and Are Affected by Sexual Media, u: K. E. DILL (ur.), The Oxford Handbook of Media Psychology, New York, Oxford University Press, 2013, 223-251). Spomenimo ovdje i primjer Wonder Woman kao počasne ambasadorice za osnaživanje žena i djevojaka pri Ujedinjenim narodima koja je izgubila titulu zbog 45 tisuća ljutitih potpisnika peticije. Kao razlog naveden je loš utjecaj na percepciju vlastitog tijela. Usp. Wonder Woman izgubila posao počasne ambasadorice UN-a, https://voxfeminae.net/ vijestice-list/svijet/item/11106-wonder-woman-izgubila-posao-pocasne-ambasadorice-un-a/ (14.12.2016).
} 
načine uzore koji nadahnjuju novu generaciju da postigne pun potencijal, bez rodnih ograničenja. $\ll^{19}$

I dok današnje filmske junakinje neki smatraju »osnaženim ženama konzumerističkog društva «, ${ }^{20}$ drugi ih vide kao »kontradiktoran odgovor i dalje patrijarhalnog društva na ženska potraživanja istog tretmana«. ${ }^{21}$ Shodno tome možemo promotriti filmski prikaz poslovnih žena. ${ }^{22}$ Naime, u radnoj okolini one najčešće nastavljaju imati skrbnu ulogu u liku tajnica, medicinskih sestara, učiteljica, odgajateljica i sličnih profesija. S druge strane, ako su i prikazane $u$ stereotipno muškom svijetu zločina, zakona, znanosti, sporta, akcije i avanture, ženstvenost njihova lika nadoknađuje se prikazom sexy tijela ili sekvencama iz privatnog života - najčešće brige oko djece i kućanstva ili ljubavne drame. Margaret W. Matlin osmislila je zgodan način provjere seksizma u medijskom prikazu žene - pokušajmo zamisliti muškarca u istoj ulozi i ako je scena bizarna riječ je o stereotipizaciji rodnih uloga. ${ }^{23}$ Istina, film je učinio korak naprijed, barem kvantitativno, što se tiče prikaza žena, ali to ne znači da su likovi razrađeniji, samostalniji ili da imaju svoj svijet koji se ne vrti oko muškarca, ${ }^{24}$ iako ne možemo ne uočiti da je posljednjih godina filmska industrija ipak iznjedrila snažne, autonomne i nestereotipne ženske protagonistice poput Imperatore Furiose u Mad Maxu: Divlja cesta (George Miller, 2015.), Myrtle Dunnage u Krojačici (Jocelyn Moorhouse, 2015.), Elizabeth Sloane u Gospođici Sloane (John Madden, 2016.), Lorraine Broughton u Atomskoj plavuši (David Leitch, 2017.), Wonder Woman ${ }^{25} \mathrm{u}$ istoimenom filmu (Patty Jenkins, 2017.) itd.

Cilj ovog članka jest upravo istražiti modernu akcijsku junakinju u filmu 21. stoljeća budući da smatramo da se najveći pomak u nestereotipnom prikazu žene dogodio upravo unutar ovoga žanra (ili bi barem tako trebalo biti). Uz to, u posljednjih desetak godina publici je predstavljen velik broj novih filmova i novih-starih likova ovog žanra. Bilo da je inspiracija pronađena u književnosti, stripu, nekom drugom obliku umjetnosti ili je ideja sasvim nova, analiziranim likovima jedno će biti zajedničko - oni su glavni likovi, tj. protagonisti radnje (likovi iz čije je perspektive ispričana priča) ili imaju veću sporednu ulogu (likovi koji se pojavljuju u više od jedne scene te su od iznimne važnosti za odvijanje

${ }^{19}$ O. MORGAN, C. SHIPMAN, Why Gender Equity Is Common Sense, u: Watching Gender. How Stereotypes in Movies and on TV Impact Kids' Development, 2-5, 5.

${ }^{20}$ G. PEVERE, Bumming-down Hollywood Women, The Toronto Star, 18. srpnja 2003., 1-3.

${ }^{21}$ K. ROSS, B. CAROLYN, Women and Media: A Critical Introduction, Malden, Blackwell, 2006, prema R. DUTT, Behind the Curtain. Women's Representations in Contemporary Hollywood, disertacija, London, The London School of Economics and Political Science, 2014, 9.

${ }^{22}$ Usp. Dutt, Behind the Curtain..., 84.

${ }^{23}$ Usp. M. W. MATLIN, The Psychology of Women, Belmont, Thomson Wadsworth, 2008, prema Penezić, Šunjić, Mediji, ženska rodna uloga i rodni stereotipi..., 80-81.

${ }^{24}$ Dutt, Behind the Curtain..., 10.

${ }^{25} \mathrm{Ovu}$ smo superjunakinju uvrstili u popis nestereotipnih ženskih protagonistkinja poradi osobina kao što su nestereotipno ženska tjelesna snaga, borbenost, autonomnost i snažan karakter, međutim smatramo da je njezin tjelesni izgled i dalje prikazan stereotipno kao objekt žudnje i muškog pogleda. 
radnje) u akcijskom filmu. Budući da holivudske blockbustere možemo gledati u gotovo svim kinima svijeta, takva dominacija jedne zabavljačke i kulturne industrije znači i nametanje holivudskog, odnosno američkog načina i pogleda na život i životne vrijednosti kroz relativno čvrste žanrovske i marketinške formule koje se sviđaju većini publike i donose velik profit. ${ }^{26} \mathrm{Uz}$ to, takozvani blockbusteri dio su odrastanja, a što je duža izloženost stereotipima i seksualizaciji kasnije ih je teže prepoznati. Iz tog ćemo razloga u obzir uzeti isključivo sjevernoameričke akcijske filmove. Dugi niz godina upravo su akcijski filmovi među najgledanijim i najiščekivanijim filmovima u kino dvoranama diljem svijeta. Turković objašnjenje pronalazi u osjećaju zadovoljstva prilikom gledanja kadrova uništenja i borbi te smatra da se razlog za takav osjećaj nalazi još u najranijem djetinjstvu. ${ }^{27}$

Vodeći se pitanjem tko je suvremena filmska akcijska junakinja, je li ona i koliko emancipirana te u kojem odnosu stoji s muškim protagonistima, odlučili smo provesti analizu sadržaja deset financijski najuspješnijih akcijskih filmova prema izvješću »Yearly Box Office« između 2007. i 2016. godine. ${ }^{28}$ Polazišna hipoteza je da akcijski filmovi i dalje obiluju rodnim stereotipima.

\section{Prikaz žena na filmskom platnu}

Prije negoli iznesemo i prokomentiramo podatke istraživanja, osvrnut ćemo se na dosadašnje analize prikaza žena u filmu te dati svojevrstan teoretski okvir i iznijeti status quaestionis s obzirom na našu temu - rodno portretiranje u filmu s osvrtom na akcijske filmske junakinje. Poseban naglasak stavit ćemo na feministički prikaz odnosa prema ženskim likovima i to kroz teoriju britanske teoretičarke filma Laure Mulvey kako ga je početno iznijela u svom eseju Visual pleasure and narrative cinema 1975. godine..$^{29}$ Međutim, najprije ćemo iznijeti

\footnotetext{
${ }^{26}$ Isto, 2.

${ }^{27}$ Turković ovu tvrdnju tumači na sljedeći način: »Sitna djeca fascinirana su destrukcijama koje sama izazivaju nad igračkama i stvarima jer, čini se, destrukcija je najdjelotvorniji način da vlastitim tjelesnim potezima izazovu najočitije posljedice [...] [a] odraslima se, nasuprot odloženo djelotvornom, a napornome dugoročnome građenju složenih tvorevina uz mnogostruke kontrole, uvijek javlja kao mogući opuštajući spas alternativa trenutačne destrukcijske djelotvornosti. [...] Kao da suvremeni maštatelj osobito uživa gledati kako se nesmiljeno razara ono što on sam u svojem životu gotovo kultno njeguje i štiti od najmanjeg oštećenja (auti, zgrade, namještaj) i što je ugrađenim običajima krajnje zaštićeno. Noviji je civilizacijski dodatak neobaziranje prema vlastitom razaranju: junaci [...] bivaju razorno pogođeni, raskrvavljeni, temeljito 'oštećeni', ali to ih jedva zaustavlja - i dalje funkcioniraju kao nesmiljene razaračke mašine« $(\mathrm{H}$. TURKOVIĆ, Suvremeni film, Zagreb, Znanje, 1999, 272-273).

${ }^{28} »$ Yearly Box Office« (2017) donosi poredak filmova s najvećom godišnjom zaradom, Box Office Mojo, http://www.boxofficemojo.com/yearly/ (20.08.2017).

${ }^{29}$ Usp. L. MULVEY, Visual Pleasure and Narrative Cinema, u: A. JONES (ur.), The Feminism and Visaul Culture Reader, London - New York, Routledge, 2003, 44-53.
} 
neke recentne podatke o prisutnosti i ženskih i muških likova u filmskoj umjetnosti.

Rodne uloge su, istina, doživjele promjene tijekom zadnjih 50 godina, no medijski prikazi te promjene ne prate uvijek, već odražavaju i jačaju rodnu nejednakost. Tako, na primjer, istražujući prisutnost žena u igranim filmovima i iza kamere između 2007. i 2013. uočava se da su žene zapostavljene na filmskom platnu, posebice u akcijskom filmu gdje su zastupljene u manje od $25 \%$ uloga, te da su i dalje češće prikazivane kao seksualni objekti negoli su to muškarci. ${ }^{30}$ Analiza sadržaja 2361 lika u 100 najgledanijih sjevernoameričkih filmova u 2017. godini ${ }^{31}$ pokazuje veoma slične rezultate onima od prije pedeset i više godina. ${ }^{32}$ Riječ je o zabrinjavajućim podacima s obzirom na prisutnost i prikaz žena u najgledanijim holivudskim filmovima: kao protagonistice pojavljuju se u $24 \%$ slučajeva (što je pad od $5 \%$ u odnosu na prethodnu godinu) te čine 34 $\%$ filmske populacije ako se uzmu u obzir svi analizirani filmski likovi. Tako su gledatelji u 2017. mogli vidjeti gotovo dvostruko više muških negoli ženskih likova u 100 najgledanijih američkih filmova. Svega je 32 \% filmova imalo deset ili više ženskih likova, dok su se muškarci s tom brojčanom zastupljenošću pojavili u čak 79 \% filmova. Što se žanrova tiče, žene se i dalje najčešće pojavljuju u komedijama (30 \%) i dramama (30 \%), te u $17 \%$ akcijskih filmova, dok su muškarci najčešće protagonisti u akcijskim filmovima (38 \%) i komedijama (20\%).

Zanimljivo je naglasiti i to da je istraživanje još jednom potvrdilo da su ženski likovi uglavnom mlađe životne dobi od njihovih muških partnera: one su najčešće u dvadesetima i ranim tridesetima, dok su muški likovi uglavnom u tridesetima i četrdesetima. U 2017. godini 68 \% svih ženskih likova bile su bjelkinje. Ženskim se likovima češće naglašava njihov bračni status (53 \%) negoli se to čini muškim likovima (40\%), a ovim potonjima češće je istaknuto zanimanje kojim se bave (78 \% vs. $63 \%$ ). Stoga ne čudi da je više muških likova prikazano na radnome mjestu ( $69 \%$ vs. $55 \%$ i u ulozi lidera ( $8 \%$ vs. $5 \%)$, te da su muškarci češće prikazani kao oni koji se vode poslovnim ciljevima ( $42 \%$ vs. $34 \%$ ), a žene

\footnotetext{
${ }^{30}$ Usp. L. S. SMITH, M. CHOUEITI, K. PIEPER, Gender Inequality in Popular Films: Examining On Screen Portrayals and Behind-the-Scenes Employment Patterns in Motion Pictures Released between 2007-2013, http://annenberg.usc.edu/pages/ /media/MDSCI/Gender\%20 Inequality\%20in\%20Film\%202007-2013\%20Final\%20for\%20Publication.ashx (10.07.2017); G. GERBNER, Violence in Television Drama. Trends and Symbolic Functions, u: G. S. COMSTOCK, E. A. RUBINSTEIN (ur.), Television and Social Behavior, Washington, U.S. Government Printing Office, 1972, 28-187; N. SIGNORIELLI, A. BACUE, Recognition and Respect. A Content Analysis of Primetime Televison Characters Across Three Decades, Sex Roles, 40 (1999) 7-8, 527-544; S. D. WITT, The Influence of Television on Children's Gender Role Socialization, Childhood Education. Infancy Through Adolescence, 76 (1999) 5, 322-324.

${ }^{31}$ Usp. M. M. LAUZEN, It's a Man's (Celluloid) World. Portrayals of Female Characters in the Top 100 Films of 2017, https://womenintvfilm.sdsu.edu/wp-content/uploads/2018/03/2017 Its_a_Mans_Celluloid_World_Report_3.pdf (02.07.2018).

${ }^{32}$ Usp. D. W. SMYTH, Three Years of New York Television, 1951-1953, Urbana/Illinois, National Association of Educational Broadcasters, 1953; S. HEAD, Content Analysis of Television Dramatic Programs, The Quarterly of Film Radio and Television, 9 (1954) 2, 175-194.
} 
privatnim (20 \% vs. $13 \%)$. Istraživanje je pokazalo i u slučaju kada su redateljice ili scenaristice bile žene, ženskih je likova bilo $45 \%$, za razliku od muških redatelja/scenarista kod kojih su žene tek u $20 \%$ bile protagonistice radnje. Isto tako, ženski se likovi češće pojavljuju u nezavisnim filmskim produkcijama, a muški u filmovima velikih holivudskih studija. Jedan od razloga predominacije muških heroja u filmovima, ili ono što će Atteberry okarakterizirati kao: »Žena je iznimka; muškarac je tvornička postavka «, ${ }^{33}$ jest i taj što se iza kamere najčešće nalaze muškarci u ulogama producenata, redatelja i scenarista. ${ }^{34}$ Oni tako, »svjesno ili ne, cijene priče i dostignuća muškaraca vjerujući da su ona zanimljivija od ženskih. (...) S takvim prevladavajućim muškim okruženjem, obiluju mogućnosti za seksizam bilo namjerno bilo nenamjerno ${ }^{35}$ Stoga su stihovi pjesme »This is a Man's Man's Man's World« Jamesa Browna iz 1966. godine, čini se, i dalje aktualni.

No kakva je situacija bila u ranijim desetljećima što se tiče rodne reprezentacije u filmovima? Istraživanja i teorijska promišljanja filma i televizijskih serija započinju buđenjem feminističke svijesti šezdesetih godina prošloga stoljeća, s posebnim interesom za prikaz žena u medijima, dok će se znanstveni interes za prikaz muškaraca pojaviti tek u devedesetima. Kada piše o klasičnom filmu iz 1940-ih godina, Mary Ann Doane kaže:

»Bolesti i žene imaju nešto zajedničko - obje su društveno podcijenjene i neželjene, marginalizirane čestice koje neprestano prijete da prodru i zaraze ono što je važno, a to su zdravlje i muškost. « ${ }^{36}$

U filmovima koje analizira, a koji nastoje pratiti žensku subjektivnost i čežnju, žene su redovito prikazivane u okviru tradicionalno ženskih stereotipa i kao one s poremećajem osobnosti, histerične, paranoične, neurotične, mazohistice, jednom riječju one koje pate od različitih »ženskih mušica«. Pretjerana senzualnost, razuzdana strast ili loša sreća u vezama s muškarcima česti su uzroci samoubilačkih namjera ili drugih psiholoških poremećaja žena. Prikazane kao depresivne, nestabilne, nekompetentne i slabe, žene postaju predmet muškog nadzora i moći; one padaju pod mušku skrb čija je zadaća ženu spasiti od sebe same, pa će onda ti isti muškarci definirati ženski identitet i njihove že-

${ }^{33}$ B. ATTEBERRY, Beyond Captain Nemo, u: E. BELL i dr. (ur.), From Mouse to Mermaid. The Politics of Film, Gender, and Culture, Bloomington, Indiana University Press, 1995, 148-160, 153.

34 Žene u holivudskoj industriji čine tek 25 \% producenata i 13 \% redatelja [usp. K. SWEENEY, Girls Make Movies. The Emergence of Women-led Filmmaking Initiatives for Teenage Girls, Afterimage, 33 (2005) 3, 37-42].

${ }^{35}$ J. T. DECKER, The Portrayal of Gender in the Feature-Length Films of Pixar Animation Studios. A Content Analysis, A thesis submitted to the Graduate Faculty of Auburn University in partial fulfillment of the requirements for the Degree of Master of Science, Auburn/Alabama, 2010, $10,12$.

${ }^{36}$ M. A. DOANE, The Desire to Desire. The Woman's Film of the 1940's, Bloomington, Indiana University Press, 1987, 38. 
lje. ${ }^{37}$ Pedesetih godina prošlog stoljeća radnja mnogih filmova bila je smještena uglavnom u kućni ambijent, a nositelj radnje bila je tradicionalna obitelj s tradicionalnim rodnim ulogama: dominantnost i autoritet su tako bili pridržani suprugu i ocu, dok su supruge i majke bile submisivne skrbnice. ${ }^{38}$ Holivudska kinematografija je sve do devedesetih godina kao pokretača radnje imala gotovo isključivo muškarca, dok je žena bila pasivni predmet muškarčeva uživanja, ${ }^{39}$ a kao tipičan primjer ovih tvrdnji možemo navesti seriju filmova o najpoznatijem svjetskom tajnom agentu Jamesu Bondu. Svako desetljeće filmske umjetnosti donosilo je sve agresivnije i nasilnije muškarce, a takvo prikazivanje vrhunac će dostići u osamdesetima s akcijskim junacima koje su par excellence utjelovili Sylvester Stallone i Arnold Schwarzenegger.

Neki autori smatraju da je u Hollywoodu ipak došlo do svojevrsnog pomaka u prikazivanju ženskih likova 1990-ih predstavljajući veću raznolikost ženskih uloga i muškog ponašanja. ${ }^{40}$ Razlog tomu je svakako i želja da se pridobije nova ciljana publika: snažne i osviještene žene koje svoje uzore traže i na velikom platnu pa će napokon moći uživati u snažnim i samosvjesnim heroinama koje prkose svim stereotipima kao što su Louise u Thelma i Louise (Ridley Scott, 1991.), Sarah Connor u Terminatoru 2: Sudnji dan (James Cameron, 1991.), Idge u Pohanim zelenim rajčicama (Fannie Flagg, 1991.), Clarice Starling u Kad jaganjci utihnu (Jonathan Demme, 1991.), dr. Ellie Sattler u Jurskome parku (Steven Spielberg, 1993.), Jackie Brown u Jackie Brown (Quentin Tarantino, 1997.), Marge Gunderson u Fargo (Ethan i Joel Cohen, 1996.) itd. Međutim, ono što se nije promijenilo jest čest stereotipan prikaz tijela: $u$ filmovima su i dalje prisutni erotizacija i stereotipizacija muškog i ženskog mišićavog i mršavog mladog tijela. ${ }^{41}$

Devedesetih godina prošlog stoljeća dolazi i do promjene u karakternom opisivanju muškaraca pa su sada oni nježniji, brižniji i emotivniji, međutim priče su i dalje ispripovijedane s njihova gledišta. Ipak, već se krajem devedesetih

\footnotetext{
${ }^{37}$ Usp. Doane, The Desire to Desire...

${ }^{38}$ Usp. D. N. RODOWICK, The Difficulty of Difference. Psychoanalysis, Sexual Difference, and Film Theory, London, Routledge, 1991.

${ }^{39}$ Usp. S. COHAN, I. R. HARK, Screening the Male. Exploring Masculinities in Hollywood Cinema, London, Routledge, 1993. Međutim, i u razdoblju klasičnog holivudskog filma postoje žanrovi i filmovi koji se u nekim segmentima otklanjaju od stereotipiziranih tendencija prikaza žena, kao što su screwball komedije u kojima se ženski likovi prikazuju kao ravnopravni i samostalni u odnosu na svoje muške pandane, te kao oni koji su aktivni subjekti u kontroli naracije, pogleda i žudnje. Više o ovoj temi usp. O. KRAUSE, Bringing Up Equality: Gender in Howard Hawks' Screwball Comedy »Bringing Up Baby«, GRIN Publishing, 2014.

${ }^{40}$ Usp. M. ELASMAR, K. HASEGAWA, M. BRAIN, The Portrayal of Women in U.S. Prime Time Television, Journal of Broadcasting \& Electronic Media, 44 (1999) 1, 20-34.

${ }^{41}$ Usp. A. SMELIK, Lara Croft, Kill Bill, and the Battle for Theory in Feminist Film Studies, u: R. BUIKEMA, I. VAN DER TUIN (ur.), Doing Gender in Media, Art and Culture, Oxford, Routledge, 2009, 178-192, 181-183.
} 
godina prošlog stoljeća ponovno vraćamo seksualnoj objektivizaciji žena ${ }^{42}$ kao predmeta muške žudnje i njihovim ulogama u romantičnim narativima, te dominantnim i agresivnim muškarcima. Henry će taj trend povezati s osnaživanjem post-feminističkog pokreta te muškog straha od gubitka tisućljetne moći pa će »pravog" muškarca opet definirati fizička snaga, neemotivnost, agresija i poslovna moć (tzv. »hard masculinity $)^{43}$ kao oblici obrambenih mehanizama. ${ }^{44}$ Thompson će filmove s takvim filmskim junacima u šali nazvati »dick flicks« kao antipod stereotipno ženskim romantičnim filmovima koji se u popularnoj kulturi nazivaju »chick flicks«. ${ }^{45}$

\section{Muško zurenje u ženski objekt žudnje}

U eseju iz 1975. godine Visual Pleasure and Narrative Cinema koji se bavi prikazom roda u holivudskom filmu, Laura Mulvey opisala je ulogu žena na filmu kao objekta vizualnog užitka za muške likove i mušku publiku. ${ }^{46} \mathrm{Ma}$ instream filmovi obično zauzimaju androcentričnu poziciju te pričaju priče kroz optiku muškog iskustva, učeći muškarce da budu agresivni i dominantni, a žene submisivne i pasivne. ${ }^{47}$ Stoga film prikazuje, otkriva i igra se isključivo društveno prihvatljivim prikazom žene kroz kontrolirane slike, erotičnost $\mathrm{i}$ spektakl. Mulvey govori o »paradoksu falocentrizma« koji uvelike ovisi o prikazu nemoćne žene. Ona zapravo želi reći da žene u filmskoj industriji nisu stvaratelji značenja već alat putem kojeg muški glasovi žive. ${ }^{48}$ Nadalje, osvrće se na užitke koje film pruža, a posebno ističe voajerizam i skopofiliju. Iako smo svjesni da sve što je prikazano na filmu ima svoju svrhu i namjerno je uključeno, autorica smatra da masovnost današnje kinematografije, kao i razlika publike u tami i sjajnog ekrana kao prozora, ponovno razdvaja i zadovoljava navedene užitke. No, nasuprot skopofiličnog (libidnog) stoji narcisoidni ego koji dolazi iz identifikacije s onime što vidimo i gledamo. Kada govorimo o pogledu u filmu, na ženu gledamo kao na sliku, a ne nositelja pogleda. Taj fenomen ona naziva »muško zurenje« (male gaze) čime označava pasivnu ženu i pogled na nju od

\footnotetext{
${ }^{42}$ Usp. A. McROBBIE, Post-feminism and Popular Culture, Feminist Media Studies, 4 (2004) 3, 255-262.

${ }^{43}$ Engleski termin »hard masculinity« mogli bismo prevesti kao »žestoku muževnost«.

${ }^{44}$ Usp. M. HENRY, He is a »Bad Mother*\$\%@!\#«. Shaft and Contemporary Black Masculinity, African American Review, 38 (2004) 1, 1-9.

${ }^{45}$ Termin »chick flicks« u slengu se koristi za filmski žanr ljubavne, romantične i općenito »srcedrapateljne« tematike namijenjen tipično ženskoj publici, a termin »dickflicks« bi se u tom smislu odnosio na »muške« filmove nabijene akcijom i testosteronima; usp. N. M. THOMPSON, The Chick Flick Paradox, Women and Media, 37 (2007) 1, 43-45.

${ }^{46}$ Usp. Mulvey, Visual Pleasure and Narrative Cinema, 44-53.

${ }^{47}$ Usp. M. HEDLEY, The Presentation of Gendered Conflict in Popular Movies. Affective Stereotypes, Cultural Sentiments, and Men's Motivation, Sex Roles, 31 (1994) 11-12, 721-740.

${ }^{48}$ Usp. Mulvey, Visual Pleasure and Narrative Cinema..., 44.
} 
strane aktivnog muškarca. Mulvey se poziva i na Budda Boettichera kada opisuje »nevažnost« ženskog lika. Naime, žena može biti uzrok emocija koje će potaknuti junaka filma na djelovanje, no ona sama nikada nije pokretač radnje. Stoga junakinja ima dvije uloge - služi kao objekt erotizacije muškim likovima, ali u isto vrijeme i publici. Poistovjećivanjem s muškim likom, jer iz njegova rakursa gledamo radnju, zapravo dobivamo i osjećaj svemoći, odnosno dojam odraza u zrcalu. ${ }^{49}$ Lidija Cvetić to tumači na sljedeći način: diskurs određuje kakva će slika biti, ali konstruira vizualni prikaz kolektivne svijesti kroz koju se stvara i identitet. Zbog toga je

»filmski kadar organiziran oko: aktivnog muškarca kao nosioca pogleda i pasivne žene kao objekta koji taj pogled trpi. [...] Muški lik postaje ekranski zastupnik gledaoca [...], žena postaje [...] vlasništvo gledaoca.$^{50}$

Time je užitak gledanja podijeljen između aktivnog/muškog i pasivnog/ ženskog, a što ženu automatski stavlja u podređen položaj. Ili kao što kritičar kulture John Berger piše u svojoj klasičnoj studiji Ways of Seeing s obzirom na čitavu povijest vizualne kulture Zapada:

»Muškarci djeluju, žene se pojavljuju. Muškarci promatraju žene. Žene promatraju kako ih se promatra. To ne određuje samo odnose muškaraca i žena već i odnos žena prema sebi. ${ }^{51}$

Pretpostavlja se dakle da je prototip idealnog gledatelja muškog roda, pa je slika žene konstruirana tako da ugodi muškarcu. To možemo primijetiti prateći zapadnu povijest umjetnosti i vizualne kulture, posebno likovnu umjetnost od 17. stoljeća naovamo u kojoj slike ženske golotinje odražavaju žensku podređenost »vlasniku i žene i slike «, ${ }^{52}$ a isti se trend nastavlja u suvremenim filmovima, reklamama, videospotovima i ostalim medijskim proizvodima koji su konstruirani iz muške perspektive i u kojima je žena prikazana kao objekt žudnje, dok je njeno razgolićeno tijelo u stanju prodati sve, od igle do aviona. Mulvey u tom smislu poziva na »uništenje užitka kao radikalnog oružja «, ${ }^{53}$ što je nužan preduvjet da žene zadobiju moć nad načinom na koji ih se prikazuje u medijima kao i autonomnu simboličnu formu, »neki novi jezik žudnje « ${ }^{54}$ koji će se artikulirati $u$ i putem filma te stati nakraj nametnutom gledanju iz muške perspektive, tj. voajerističkom zurenju. To čini jedna od najproučavanijih akcijskih heroina, ključna za feminističku teoriju filma te izuzetak koji potvrđuje (Mulveyino) pravilo - lik Ellen Ripley (Sigourney Weaver) iz filma Alien (Ridley Scott, 1979). Ona se smatra prvom akcijskom junakinjom koja je svoj kultni

\footnotetext{
${ }^{49}$ Usp. isto, 48.

${ }^{50}$ L. CVETIĆ, Žensko telo u nadrealističkoj fotografiji i filmu, doktorska disertacija, Beograd, Univerzitet umetnosti u Beogradu, 2015, 17-18.

${ }^{51}$ John BERGER, Ways of Seeing, London, Penguin Books, 1972, 47.

${ }^{52}$ Isto, 52.

${ }^{53}$ Mulvey, Visual Pleasure and Narrative Cinema..., 44.

${ }^{54}$ Isto, 45.
} 
status uspjela zadržati godinama - lukav, snalažljiv, dinamičan lik, te iako »zauzima takozvanu mušku privilegiju aktivnog subjekta kroz proces postajanja aktivne junakinje, ona niti oponaša muškaraca, niti postaje muškarcem « ${ }^{55}$ te $u$ tom smislu »razbija hijerarhijsku podjelu na aktivno-muško/pasivno-žensko«. ${ }^{56}$

U okviru Mulveyine feminističke kritike filma, Anneke Smelik analizira ženske protagonistice Laru Croft (Angelina Jolie) iz Tomb Raidera (Simon West, 2001.) i Beatrix Kiddo (Uma Thurman) iz Kill Billa (Quentin Tarantino, 2003.). Oba lika su prema autorici fizički prekrasna, ali ujedno su im pripisane i muške osobine budući da je riječ o akcijskim heroinama. Lara Croft nema ljubavnih partnera, općenito nema nekih emocionalnih izazova u filmu, a Beatrix Kiddo je, uz emancipiranu ženu-ratnicu, i majka. No, njen motiv da spasi dijete saznajemo tek na kraju, zato što biti majka nije seksi u današnjem Hollywoodu. ${ }^{57}$ Muški strah od ženskog tijela Mulvey prepoznaje kroz oblike sadizma kao što su scene silovanja ili ubojstvo fatalne žene, te uzdizanje i erotiziranje ženske ljepote čak do granice zapostavljanja radnje, a što Smelik prepoznaje kod Lare Croft u Tomb Raideru. ${ }^{58}$ Smelik smatra da se tipični voajerizam u holivudskom filmu smanjio, odnosno da radnju filma više ne gledamo kroz oči muškog protagonista zbog sve veće, svjesnije i zahtjevnije ženske publike koja na filmskome platnu traži svoje uzore u likovima dominantnih žena; ono što se međutim nije promijenilo jest prikaz tijela. Štoviše, primjećuje erotizaciju i stereotipizaciju ne samo ženskog već i muškog tijela, i to netipičnog, mišićavog, mršavog, mladog tijela. ${ }^{59}$ Nadalje, pri analizi likova koristi i psihološku teoriju identifikacije s vlastitim odrazom, koji dolazi izvan osobe, takozvani narcistički »gaze«, a koji se pojavljuje u najranijem djetinjstvu. Jasna je razlika između dvaju pogleda - narcisoidnog i skopofiličnog: prvi je usmjeren na sebe, dok voajerizam gleda drugoga. Prvi dolazi iz želje da budemo netko, a drugi da imamo. ${ }^{60}$ Smelik tako filmu pripisuje karakteristike ogledala u kojemu će "gledatelj prepoznati svoj idealni 'ja' (ego)«. Glavna razlika između ta dva analizirana filma, odnosno prikaza njihovih junakinja, jest u tome što se, za razliku od Lare Croft, tijelo Beatrix Kiddo nikada ne erotizira voajerističkim gazeom, ali je izražen onaj narcisoidni i to kroz njen odnos s oružjem - mačem koji pruža odraz. ${ }^{61}$

U svom istraživanju obiteljskih filmova između 1990. i 2006. godine, Stacey L. Smith i Marc Choueiti zaključuju da je čak i u ovom žanru žena samo ukras

\footnotetext{
${ }^{55}$ E. HILLS, From »Figurative Males« to Action Heroines: Further Thoughts on Active Women in the Cinema, Screen, 40 (1999) 1, 38-50, 45.

${ }^{56}$ Isto, 43.

${ }^{57}$ Usp. Smelik, Lara Croft, Kill Bill, and the Battle..., 185, 189, 191.

${ }^{58}$ Usp. isto, 181.

${ }^{59}$ Isto, 181-183.

${ }^{60}$ Isto, 184-186.

${ }^{61}$ Isto, 188-189.
} 
koji je mlad, zgodan i to se ne libi pokazati odabirom odjeće. ${ }^{62}$ Dutt je, na primjer, svoje istraživanje temeljila na tri najuspješnija filma 2013. godine - Osvetnici (Joss Whedon, 2012.), Harry Potter $i$ darovi smrti - 2. dio (David Yates, 2010.) i Priča o igračkama 3 (Lee Unkrich, 2010.). Semiotičkom analizom protagonistica zaključila je da postoje stanoviti načini na koje se žene predstavljaju u današnjem Hollywoodu. Primjerice, Natashu Romanoff (Scarlett Johansson) u Osvetnicima vidi kao stereotipno lijepu ženu koja zadovoljava žanr akcijskog filma, ali ju se ne pokazuje kroz romantičan odnos s muškarcem, iako film i dalje naglašava da društvo vode muškarci. S druge strane, Hermionu (Emma Watson) u Harryju Potteru i Jessie u Priči o igračkama film ipak smješta u stereotipne okvire prikaza rodnih uloga. ${ }^{63}$

\section{O istraživanju}

Analizom najgledanijih dugometražnih igranih filmova akcijskog žanra $u$ razdoblju od siječnja 2007. do prosinca 2016. godine (po jedan film za svaku godinu), postavili smo si za cilj otkriti kakva je moderna junakinja iz akcijskih filmova 21. stoljeća i prati li rodne stereotipe (fizički izgled, dob, veličina uloge, zaposlenje, iskazivanje osjećaja) ili je ipak došlo do promjene u njenom prikazivanju. Glavna hipoteza istraživanja jest sljedeća: Protagonistice najgledanijih holivudskih akcijskih filmova u proteklih deset godina odražavaju rodne stereotipe.

Temeljna istraživačka pitanja jesu sljedeća:

a. Postoji li nesrazmjer između broja muških i ženskih akcijskih likova?

b. Jesu li ženski likovi u akcijskim filmovima nositeljice radnje?

c. Kakve su tjelesne karakteristike ženskih likova u odnosu na muške?

d. Jesu li ženski likovi u akcijskim filmovima aktivni ili pasivni, tj. spašavaju li ili su spašavani, gledaju li ili su objekt gledanja?

e. Pokazuju li ženski likovi osjećaje češće od muških likova?

f. Imaju li ženski likovi ostvarenu poslovnu karijeru ili važan društveni položaj?

g. Prolaze li filmovi Bechdelov test? ${ }^{64}$

\footnotetext{
${ }^{62}$ Usp. Smith i dr., Assessing Gender-Related Portrayals in Top-Grossing..., 774-786; England, Descartes, Collier-Meek, Gender Role Portrayal and the Disney Princesses..., 555-567.

${ }^{63}$ Usp. Dutt, Behind the Curtain...

${ }^{64}$ Bechdelov test je metoda analize (ne)stereotipnog portretiranja ženskih likova u fiktivnim pričama, a odgovara na sljedeće pitanje: Donosi li priča barem dva ženska lika (čija su nam imena poznata) koja međusobno razgovaraju o temi koja se ne tiče muškaraca?
} 
Radi odgovaranja na navedena istraživačka pitanja, ženske i muške glavne i veće sporedne likove (njih 86) podvrgli smo analizi sadržaja kao »postupku proučavanja i raščlanjivanja verbalne ili neverbalne građe kojim se nastoje uočiti njezine osobine i poruke. ${ }^{65}$ Analiza sadržaja može biti kvantitativna i kvalitativna, a poradi malog uzorka analiziranih filmova mi ćemo koristiti obje tehnike analize. Dok kvantitativnom analizom sadržaja - definiranom kao »istraživačkom tehnikom kojom se na objektivan i sustavan način kvantitativno opisuje sadržaj nekog aspekta komunikacije « ${ }^{66}$ - utvrđujemo učestalost jedinica analize u nekom tekstu (članku, filmu, televizijskoj seriji, glazbenom spotu itd.), kvalitativna analiza sadržaja usmjerena je na otkrivanje značenjskoga konteksta jedinica analize. Hsieh i Shannon kvalitativnu analizu sadržaja definiraju kao »istraživačku metodu za subjektivno tumačenje sadržaja tekstualnih podataka kroz sustavnu klasifikaciju procesa kodiranja i identificiranja tema ili obrazaca.« ${ }^{67}$

Koristit ćemo i semiotičku denotacijsku i konotacijsku analizu o kojoj govori Roland Barthes u djelu Elements of Semiology. On, naime, ističe da konotativno i denotativno ne mora biti jedinica istog reda veličine. ${ }^{68}$ Više denotativnih simbola može tvoriti jednu konotativnu asocijaciju, primjerice: položaj i držanje tijela, odjeća i prostorni smještaj junakinje zajedno se mogu tumačiti pri sagledavanju njenog društvenog položaja i uloge.

Kriterij odabira filmova čije smo likove analizirali bila je njihova gledanost i uspješnost u smislu novčanih prihoda koje je film ostvario na svjetskoj razini (»Yearly Box Office«) kao mjerilom njegove prihvaćenosti i dosega među publikom. ${ }^{69} \mathrm{Na}$ taj način uveli smo kvantitativnost $\mathrm{u}$ istraživanje te izbjegli subjektivne kriterije poput filmskih kritika i nagrada. ${ }^{70}$ Filmovi koji su odgovarali zadanom kriteriju su sljedeći: Pirati s Kariba: Na kraju svijeta (Gore Verbinski, 2007.), Vitez Tame (2008., Christopher Nolan), Avatar (James Cameron, 2009.), Početak (Christopher Nolan, 2010.), Transformeri: Tamna strana Mjeseca (Michael Bay, 2011.), Osvetnici (Joss Whedon, 2012.), Iron Man 3 (Shane Black, 2013.), Transformeri: Doba izumiranja (Michael Bay, 2014.), Ratovi zvijezda: Sila se budi (J. J. Abrams, 2015.), Kapetan Amerika: Gradanski rat (Anthony i Joe Russo, 2016.).

\footnotetext{
${ }^{65}$ V. LAMZA POSAVEC, Kvantitativne metode istraživanja. Anketa i analiza sadržaja, Zagreb, Hrvatski studiji Sveučilišta u Zagrebu, 2011, 105.

${ }^{66} \mathrm{G}$. MILAS, Istraživačke metode u psihologiji i drugim društvenim znanostima, Jastrebarsko, Naklada Slap, 2009, 500.

${ }^{67}$ H. HSIEH, S. SHANNON, Three Approaches to Qualitative Content Analysis, Qualitative Health Research, 15 (2005) 9, 1277-1288, 1278.

${ }^{68}$ Usp. R. BARTHES, Elements of Semiology, New York, Hill and Wang, 1986, 91.

${ }^{69}$ »Yearly Box Office« (2017) donosi poredak filmova s najvećom godišnjom zaradom, Box Office Mojo, http://www.boxofficemojo.com/yearly/ (20.08.2017).

${ }^{70}$ Usp. Dutt, Behind the Curtain..., 14.
} 


\section{Rezultati istraživanja}

Rezultati analize sadržaja pokazali su da od ukupnog broja analiziranih protagonista i većih sporednih likova, točnije njih 86 , muškarci čine većinu od 60 likova (69,77 \%) dok je ženskih likova izdvojeno 26 (30,23 \%). Najviše istaknutih ženskih likova, njih četiri, imali su filmovi Avatar i Ratovi zvijezda: Sila se budi, s time da Ratovi zvijezda imaju ravnomjeran omjer zastupljenosti glavnih likova obaju spolova.

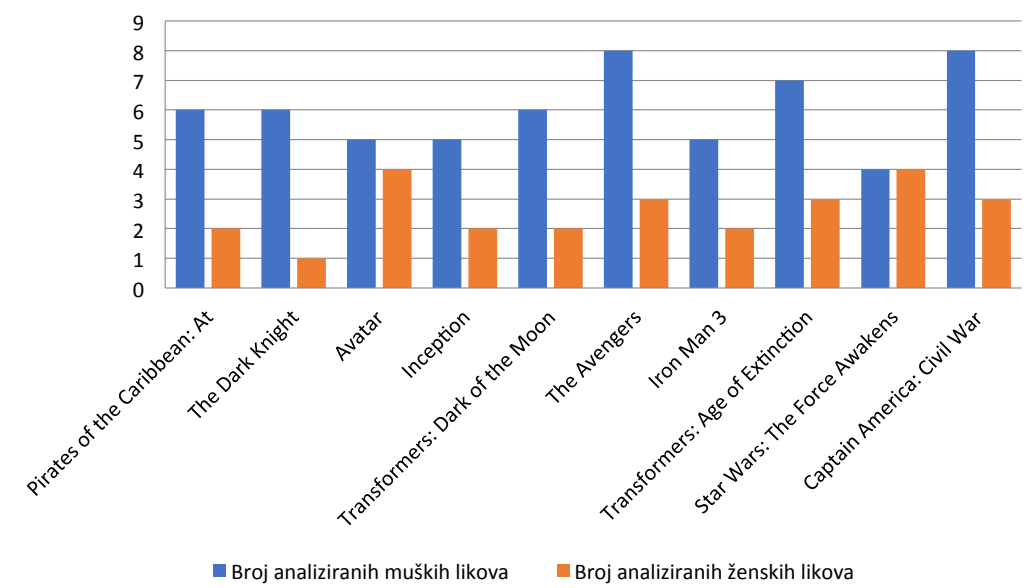

Grafikon 1. Broj analiziranih likova u filmovima

Analizirani ženski likovi uglavnom su bili s pretežito pozitivnim osobinama. Tek će šest ženskih likova pokazati nepoštivanje prema pozitivnim muškim likovima suprotstavljajući im se i ometajući im planove, od kojih tri pokazuju očito kajanje zbog takvog ponašanja. Time patrijarhalni red koji su pokušale narušiti vraćaju u normalu bivajući kažnjene zato što su se usudile suprotstaviti muškom autoritetu. Zanimljivo je i da 23 od 26 ženska lika čine pripadnice bijele rase, a kod jedne Afroamerikanke među vodećim likovima uočava se stereotipan, pomalo rasistički prikaz. Naime, iako je lik Tie Dalme (Naomie Harris) iz Pirata s Kariba zapravo lik božice Calypso, ona je zarobljenica bijelog kapetana te mora čekati svoje oslobođenje iz okova ljudskog tijela kako bi ponovno bila oslobođena i od kletve. Njena životna priča uvelike se podudara s pričom nimfe iz grčke mitologije. Drugi ženski lik koji ne ulazi u spomenuti postotak je Azijatkinja Su Yueming (Li BingBing), jedna od antagonistica Transformera koje nisu nužno zle te pri kraju filma pokazuje kajanje i pomaže u spašavanju svijeta. Nju pak krase osobine koje se inače stereotipno smatraju pretežito muškima - direktorica je tvrtke, poznaje borilačke vještine, iznimno je vješta vozačica motocikla, snažna je, odlučna i ne pokazuje emocije. Inače, istraživanje Meredith Li-Vollmer i Marka LaPointea pokazuje da je u fil- 
movima prikaz muževnosti i ženstvenosti izrazito polariziran tako da se heroji uglavnom drže tradicionalnih rodnih uloga, dok su oni koji krše ta pravila te se odaju »rodnim prijestupima « (gender transgressions) utjelovljeni u zlikovcima. ${ }^{71}$ Međutim, i junakinje protagonistice u akcijskom će žanru često kršiti tradicionalne rodne uloge i na sebe preuzeti tipično muške karakteristike kao što su hrabrost, agresivnost, samostalnost, fizička snaga, baratanje oružjem, borilačke vještine i odlučnost, a ponekad će djelovati i poput pomuškarčenih žena (slavni primjeri su likovi Furiose u Mad Maxu: Divlja cesta te Lorraine Broughton u Atomskoj plavuši [oba lika tumači Charlize Teron] - prva akcijska junakinja homoseksualnih sklonosti). Takve će akcijske junakinje u okviru feminističke filmske teorije često biti opisivane kao »pseudo-muškarci«. ${ }^{72}$

Što se tiče zastupljenosti žena u glavnim ulogama u filmu, od ukupnog broja analiziranih muških i ženskih likova njih 17 nosi karakteristiku protagonista, od čega su samo dvije žene protagonistice radnje. Riječ je o likovima Black Widow (Scarlett Johansson) u filmu Osvetnici i Rey (Daisy Ridley) iz filma Ratovi zvijezda. Rey je neovisna, samostalno uspijeva ovladati »silom« u sebi, ali i dalje je u potrazi za učiteljem koji će joj pomoći u ostvarivanju njenog punog potencijala. Zanimljivo je da, iako mlada i lijepa, nije promatrana kao seksualni objekt u filmu. Premda pogled na grafikon odaje očitu prevlast muškaraca u glavnoj ulozi, postoji još žena koje imaju značajniju ulogu, kao primjerice u Avataru ili u filmu Pirati s Kariba. Na kraju svijeta te u filmu Početak, ali iz njihove perspektive nije ispričana priča niti one ispunjavaju svoj zadatak već sudjeluju i pomažu u ispunjavaju muškarčevih želja i ambicija.

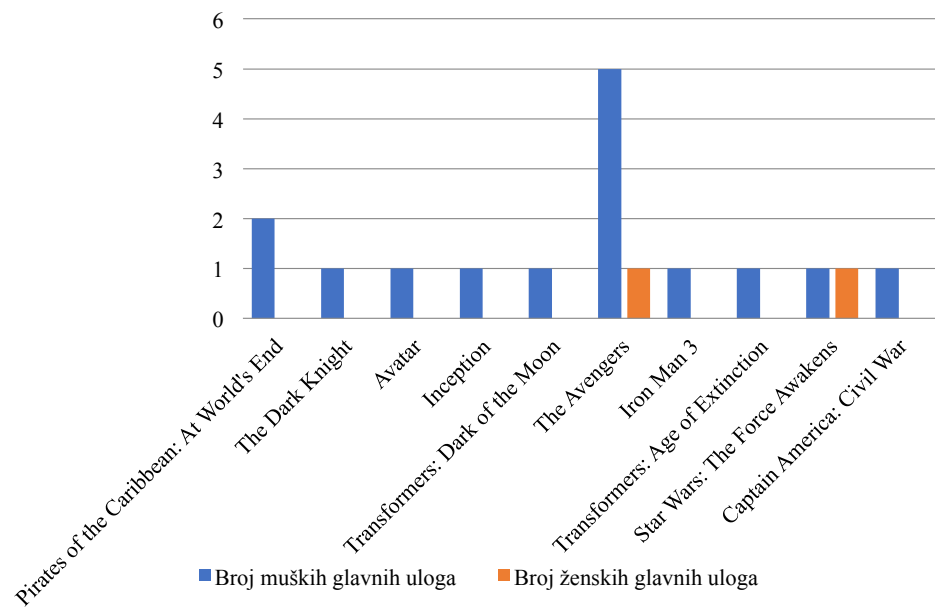

Grafikon 2. Broj analiziranih glavnih likova u filmovima

\footnotetext{
${ }^{71}$ Usp. M. LI-VOLLMER, M. LAPOINTE, Gender Transgression and Villainy in Animated Film, Popular Communication, 1 (2003) 2, 89-109.

${ }^{72}$ Usp. Hills, From »Figurative Males« to Action Heroines..., 38.
} 
S obzirom na fizički izgled muških i ženskih likova, očekivano je bilo da će se on više isticati kod žena. Međutim od ukupnog broja analiziranih muških likova, njih čak 25 od 60 ima naglašenu građu tijela. Najčešće su to atletska mišićava tijela, no to se možda i moglo očekivati s obzirom na analizirani žanr i količinu fizički zahtjevnih zadataka koji se nalaze pred likovima. Tu su ubrojeni i roboti i neljudske vrste kojima je naglašena građa tijela poput Autobota $u$ Transformerima te lik Iron Mana (Robert Downey Junior) u filmu Osvetnici jer, za razliku od, primjerice, robota iz Ratova zvijezda kao što su C3-PO, BB-8 ili R2-D2, njihovim oblikom koji podsjeća na mehaničko ljudsko tijelo dominiraju obrisi izraženih mišića. S druge strane govorimo o 12 od 26 likova kada je riječ o naglašenim fizičkim atributima kod žena. Nešto je veća razlika kada u obzir uzmemo razodjevenost likova: žena je tada 6 od 26, a muškaraca 6 od 60 .

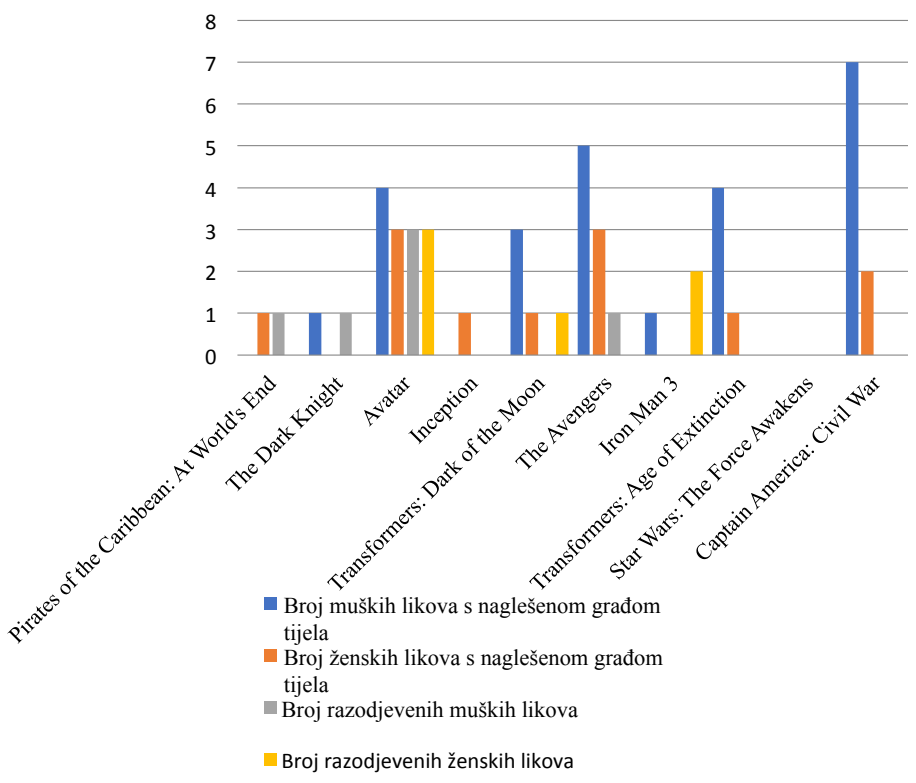

Grafikon 3. Broj likova s naglašenom građom i razodjevenim prikazom tijela u filmu

Zanimljivo je da su u svih deset filmova samo dva lika potpuno razodjevena i to jedan muškarac, Bruce Banner (Mark Ruffalo) u Osvetnicima, te Grace (Sigourney Weaver) u Avataru. Međutim, niti jedna od tih scena nije vulgarna već je više komična i u službi oslikavanja dodira s prirodom bez direktnog prikaza intimnih dijelova tijela. Zapravo, kada se pogleda grafikon rezultati se mogu na prvu činiti drugačijima, ali važno je naglasiti kako se, primjerice, u Avataru radi o plemenu koje se ne pokriva s puno odjeće, a i nisu važni samo apsolutni brojevi već njihovi odnosi i presjeci u odnosu na zastupljenost pojedinog spola.

Kada je riječ o muškom zurenju (male gaze) te pasivnoj naglašeno erotiziranoj ženi koja služi voajerističkom pogledu likova u filmu i gledateljima ispred 
filmskog platna, a o kojima je pisala Laura Mulvey, njega je bilo moguće uočiti kod polovice analiziranih likova, a nije uočen u samo tri od deset analiziranih filmova. U tom kontekstu spomenut ćemo jedan negativan i jedan pozitivan primjer. U oba nastavka Transformera, posebno u ranijem nastavku, svaki se ženski lik stavlja u kontekst seksualnog objekta bez obzira je li samo statist ili ima neku veću ulogu. Prvo upoznavanje s najvećim ženskim likom, te ujedno i scena kojom se film otvara, jest kroz krupan kadar njene stražnjice u gaćicama. Čak i žene govore o drugim ženama kroz prizmu seksualnosti i ljepote tijela. Na primjer, majka glavnog lika njegovu djevojku opisuje kao »world-class hottie $\aleph^{73}$ uopće ne spominjući njene druge kvalitete. S druge strane, imamo pozitivan primjer u megapopularnim Ratovima zvijezda gdje se niti jednom spolu ne naglašavaju tjelesni atributi niti ih se erotizira na ikakav način. Štoviše, kod lika Captain Phasma (Gwendoline Christie) ne znamo čak niti kojoj pripada, a spol pogađamo samo po boji glasa glumice jer kroz cijeli film oklop sakriva bilo kakva tjelesna obilježja.

Thompson i Zerbinos, koji su proučavali rodne stereotipe $u$ animiranim filmovima, uveli su važnu varijablu $u$ analizi rodnih poruka: akciju spašavanja. ${ }^{74}$ Tko spašava, a tko je spašen govori o tome tko ima aktivnu, a tko pasivnu ulogu te može biti snažan indikator rodne stereotipizacije:

»Dosljedni prikazi značajnih rodnih obrazaca (npr. tko je subjekt čina spašavanja) može pridonijeti društvenim skriptima koje gledatelj stvara dok je izložen rodno stereotipiziranom sadržaju. ॥ $^{75}$

U našem je slučaju istraživačko pitanje o tome jesu li ženski likovi češće spašavani (11 od 26) ili pak spašavaju (10 od 26) tek za jedan lik prevagnulo u korist pasivnije ženske uloge, one koja je spašena. U ovu statistiku nisu ubrojene tendencije spašavanja svijeta već isključivo drugih likova. Pokazalo se da žene spašavaju i spašene su od strane muškaraca, ali i spašavaju i spašene su i od strane drugih žena.

Odabrane filmove podvrgli smo i Bechdelovu testu koji je metoda vrednovanja prikaza žena u fikcijskim pričama te je jedan od pokazatelja rodne stereotipizacije. Da bi neki film prošao test nužno je da u filmu imamo barem dva ženska lika koja vode razgovor o nečemu što se ne odnosi na muškarca, te da su ta dva lika imenovana. Statistički podaci analize 7924 filma sa službene stranice Bechdelova testa pokazuju da 42,16 \% filmova ne prolazi test. ${ }^{76} \mathrm{U}$ ovom istraživanju polovica filmova test formalno prolazi (Pirati s Kariba: $\mathrm{Na} \mathrm{kraju}$

\footnotetext{
${ }^{73}$ Engleski termin »world-class hottie mogli bismo prevesti kao »prvoklasan komad $«$.

${ }^{74}$ Usp. T. THOMPSON, E. ZERBINOS, Gender Roles in Animated Cartoons. Has the Picture Changed in 20 Years?, Sex Roles, 32 (1995) 9-10, 651-673.

${ }^{75}$ F. L. GEIS i dr., TV Commercials as Achievement Scripts for Women, Sex Roles, 10 (1984) 513-525, prema England, Descartes, Collier-Meek, Gender Role Portrayal and the Disney Princesses..., 556.

${ }^{76}$ https://bechdeltest.com/statistics/ (20.12.2018).
} 


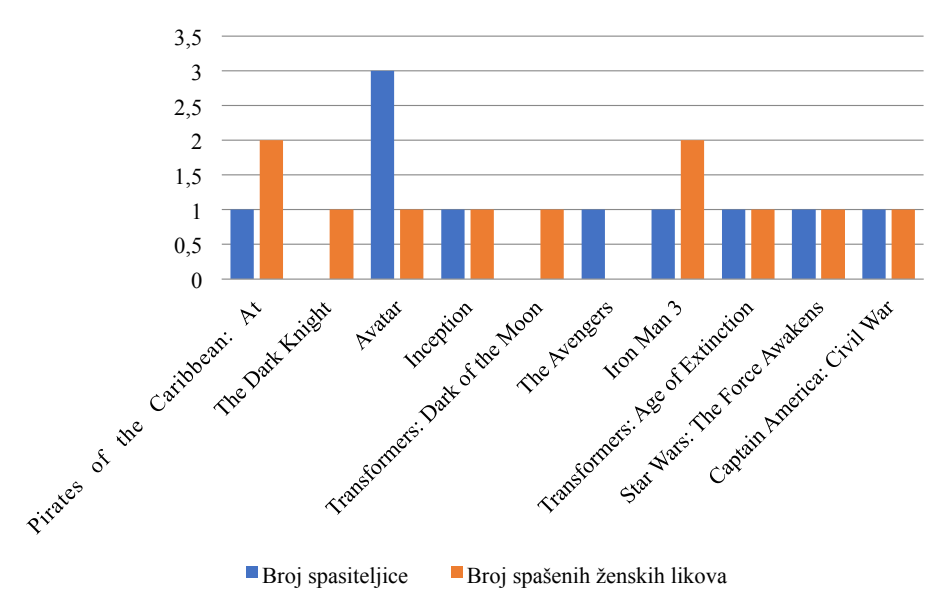

Grafikon 4. Broj spasiteljica i broj spašenih ženskih likova u filmovima

svijeta, Iron Man 3, Transformeri: Doba izumiranja, Ratovi zvijezda: Sila se budi, Kapetan Amerika: Građanski rat), međutim ostaje potreba nešto detaljnije progovoriti o ženskim razgovorima i njihovoj (ne)kvaliteti u analiziranim filmovima i to u onima koji su test prošli, a tako i u onima koji ga nisu prošli. Vitez tame je film u kojem je toliko teško pronaći ženski lik da je analiziran tek jedan - Rachel (Maggie Gyllenhaal) koja se ne obraća niti jednoj drugoj ženi u cijelom filmu. Potencijalni razgovor odvio se tek između policajke i žene načelnika Gordona, no jedna od sudionica ima pištolj prislonjen na glavu i zapravo to radi pod prisilom, te razgovor uključuje pitanje sigurnosti načelnikove obitelji tako da je zapravo opet muškarac tema njihova razgovora. U filmu Avatar ima scena u kojoj se jedan ženski lik obraća drugom, no budući da nema verbaliziranog odgovora, pitanje je je li to uopće razgovor. U ostalim ženskim razgovorima tema je muškarac, a isto vrijedi i za filmove Početak i Transformeri. Tamna strana Mjeseca, iako Početak ostavlja nešto mjesta za raspravu. Naime, Mal (Marion Cotillard) razgovara s Ariadne (Ellen Page) indirektno o muškarcu, ali ona, iako kompleksna i vrlo zanimljiva kao lik, nije stvarna već je plod sjećanja i podsvijesti muškarca pa ostaje otvoreno pitanje - ako njih dvije i ne razgovaraju o muškarcu, razgovaraju li to uopće dvije žene? Osvetnici je film koji je najviše iznenadio rezultatom jer je jedan od dvaju filmova u kojemu je protagonistica žena, te su još dva ženska lika u vodećim ulogama, no među njima ne postoji nikakva interakcija pa stoga nema nedoumice oko prolaska na Bechdelovu testu. Što se tiče filmova koji su prošli test, jedan zaslužuje poseban osvrt - Ratovi zvijezda. Snaga se budi. Naime, kada junakinja Ray razgovara s izvanzemaljkom Maz imamo jedini ženski razgovor u svim analiziranim filmovima koji u centru pažnje ima djevojku, njezinu sudbinu i važno otkriće za nju i njezinu budućnost, iako je pokretač pronalazak predmeta koji pripada muškarcu. Sve u svemu, kada je riječ o Bechdelovu testu u ovim slučajevima 
brojevi više skrivaju negoli otkrivaju pravu sliku o ženskim likovima i njihovim odnosima.

Što se tiče iskazivanja osjećaja, kao što se moglo pretpostaviti, ženski likovi pokazuju više osjećaja (njih 18 od 26 ili 69,23 \%) od svojih muških pandana (njih 28 od 60 ili 46,67 \%). Međutim broj muških junaka koji su »osjećajni« ipak nije zanemariv te vidimo da u posljednje tri godine postoji trend porasta pokazivanja emocija kod muških likova. Spomenimo tek da u analiziranim filmovima možemo primijetiti dva udovca koji otvoreno žale za svojim suprugama i motivatori su njihovih postupaka, tri ženska i četiri muška lika su zaljubljeni ili im se sviđaju likovi suprotnog spola te otvoreno pokazuju osjećaje naklonosti. Što se bračnog statusa tiče, svega su pet muškaraca i četiri žene u braku, što znači da za akcijske junake bračni status nije bitan te da se, gledano u postocima, bračni status ipak više spominje za ženske negoli za muške likove, a što je $u$ skladu s ranijim istraživanjima.

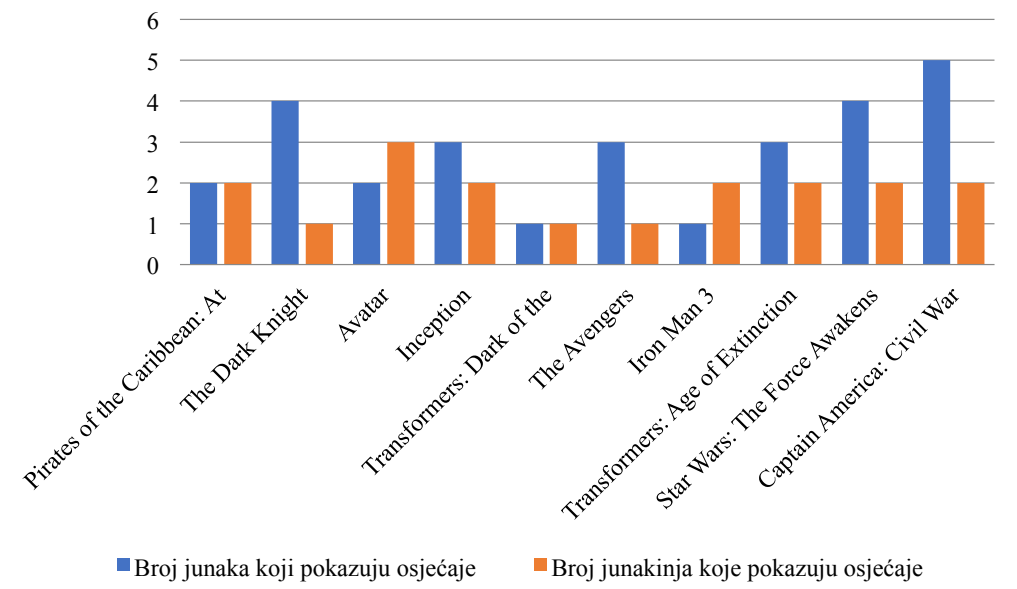

Grafikon 5. Broj junaka i broj junakinja koji pokazuju osjećaje u filmovima

Jedan od indikatora rodne stereotipizacije jest i činjenica da se ženski likovi u američkim filmovima često ne ostvaruju kroz neku profesiju niti imaju značajniju ulogu u društvenom okruženju u kojem žive, za razliku od muških likova kojima je karijera važna te ih često viđamo u poslovnom okruženju, kao lidere i nositelje važnih društvenih funkcija. Pretpostavili smo da će se isto dogoditi i u akcijskim filmovima koje smo analizirali, međutim to je mišljenje opovrgnuto budući da čak 22 od 26 ženska lika ima izraženu ulogu u društvu bilo kroz profesionalna dostignuća bilo kao važan dio zajednice (poput šamana u plemenu ili božanstva). Događa se da u nekim filmovima nije jasno definirana uloga ženskog lika. Primjerice, Black Widow u Osvetnicima jasno je nazvana špijunkom dok se isti lik u filmu Kapetan Amerike pojavljuje kao dio tima akcijskih junaka, ali nije specificirano koja je točno njezina profesija. 


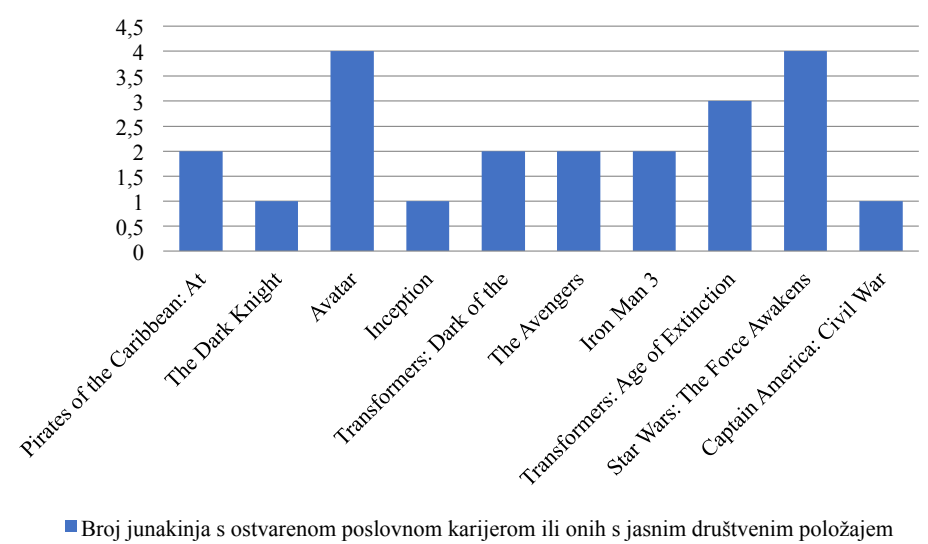

Grafikon 6. Broj junakinja s ostvarenom poslovnom karijerom ili važnim društvenim položajem u filmovima

Također, od svih analiziranih ženskih likova njih se čak 22 od 26 pokazalo samostalnima, gotovo ih polovica (12 od 26) ima barem jednu karakteristiku vođe, a čak 24 analizirane junakinje artikuliraju svoje želje i stavove.

\section{Zaključak}

Medijska industrija putem svoje zabavljačke zadaće koristi javne osobe kao takozvane influencere - lica ispred svog proizvoda ili poruke s kojima se možemo usporediti i kojima ćemo težiti - da bi što lakše približili krajnjem odredištu komunikacijskog kanala - nama, primateljima. Rezultat tog komunikacijskog procesa su razni učinci na našu percepciju svega što nas okružuje pa tako i percepciju vrijednosti žene, muškaraca, a posljedično i evaluaciju samih sebe $u$ odnosu na druge. U ovom kontekstu govorimo o dugoročnim, kumulativnim efektima koji se svakoga dana izlaganjem novim medijskim sadržajima, tako i filmu, učvršćuju u našoj psihi. Filmske poruke jednako su moćne kao i one posredovane televizijskim i radijskim emisijama ili kao one odaslane tiskom i internetom. I one obiluju stereotipima, stoga da bi pojednostavile složene društvene pojave poput rodnih uloga i seksualnosti. Tako najčešće govorimo o ženama, majkama, kraljicama koje su lijepe, drže tri, ako ne i četiri ugla kuće, a uz to, ako su dovoljno sposobne, pokušavaju graditi i poslovnu karijeru sukladno svojim mogućnostima i iznimno emotivnoj prirodi. Margaret W. Matlin dosjetila se simpatičnog načina provjere nejednakosti prikaza spolova - ako muškarac $u$ istoj ulozi kao prikazana žena izgleda bizarno riječ je o stereotipizaciji i seksističkom prikazu rodnih uloga.

Ovim se radom pokušalo dati odgovor na pitanje: Kakva je moderna junakinja iz akcijskih filmova 21. stoljeća i prati li rodne stereotipe ili je ipak 
došlo do promjene u njenom prikazivanju? Polazišna hipoteza je da akcijski filmovi i dalje obiluju rodnim stereotipima, te je ona putem niza istraživačkih pitanja metodom analize sadržaja i potvrđena, iako ne u svim segmentima. Akcijska se junakinja u ovom žanru pojavljuje rjeđe od muških likova, te je većinom pozitivan, ali sporedan lik. No, usprkos tome nije teško pronaći primjer emancipirane žene koja ispunjava vlastite želje i ambicije, a njih, usput rečeno, jasno artikulira u velikoj većini slučajeva, neovisno o veličini uloge. Čak i kada započinje u ulozi antagonista, gradi svoj stav i zna promijeniti stranu. Također, velika većina žena u analiziranim filmovima, njih gotovo $90 \%$, imalo je ostvarenu poslovnu karijeru ili istaknut društveni položaj. One svoje zadaće ostvaraju u najrazličitijim područjima u rasponu od kapetanice, sakupljačice otpada, pomoćnice državnog tužitelja, znanstvenice, direktorice, špijunskih i vojnih osoba, pilotkinje, učenice, lovkinje do duhovnih vođa.

Nadalje, istina je da su ženski likovi donekle osjećajniji od muških likova, ali ne možemo reći niti da su akcijski junaci »cijepljeni « protiv pokazivanja emocija i vezivanja za druge likove. Neke njihove ženske ljubavi progone ih čak i kada ih više nema - primjerice Mal progoni svog supruga kao dio njegove podsvijesti i grižnje savjesti, a glavnog zlikovca u filmu Kapetan Amerike motivira osveta obitelji koju doduše nikada ne upoznajemo. Kada je pak riječ o međusobnim odnosima ženskih likova, polovica analiziranih filmova prolazi Bechdelov test, iako se samo jedan može pohvaliti konstruktivnim razgovorom koji nije isključivo ukrasni element i prolazna scena, a razrađenih ženskih odnosa i ženskih prijateljstava u najgledanijim akcijskim filmovima u posljednjih deset godina nema. Potvrđena je i hipoteza koja govori o spasiteljicama i spašenim junakinjama s blagom prednošću potonjih. Gotovo njih $50 \%$ trebalo je svog heroja ili heroinu, ali i u 40 \% slučajeva one su bile nečije junakinje. Također, na polovicu ženskih likova u akcijskim avanturama gledamo još uvijek kroz muške »naočale« (male gaze), no one nisu jedine kojima se naglašava građa tijela. Budući da je to, iako u malo manjem postotku, slučaj i kod muških mišića možemo zaključiti da je to više karakteristika akcijskog žanra, a ne samo akcijske junakinje.

Konačno, akcijska junakinja je najčešće bijela, emancipirana, emotivno inteligentna žena, ali bez dubljih odnosa među kolegicama. Ona voli lijepu, ponekad oskudnu odjeću koja joj komplimentira figuru, ali je nećemo prečesto vidjeti bez nje. Iako različite, kao i žanrovi u kojima su prikazane, možemo primijetiti skup sličnih osobina koje one dijele već godinama, a ako bi se morao izdvojiti najbolji primjer od ponuđenih deset koji najuspješnije izbjegava rodne stereotipe, onda izdvajamo film J. J. Abramsa iz 2015. godine - Ratovi zvijezda. Sila se budi, no teško da to možemo pripisati evoluciji akcijske junakinje kroz godine jer i prije su postojale kompleksne, nestereotipne i dobro razrađene heroine, a pojavljuju se i kasnije u nekim drugim uspješnicama koje nisu ušle u naš filmski uzorak. 
Ovo je istraživanje dakle potvrdilo postojanje rodnih stereotipa u najgledanijim akcijskim filmovima između 2007. i 2016. godine; u nekim segmentima stereotipi su bili manje prisutni nego što smo pretpostavili (poput profesionalnog života ženskih likova, iskazivanja emocija kod muških likova), dok su podaci koji još uvijek upućuju na žensku podčinjenost u holivudskoj kinematografiji ovi: ženski su likovi u glavnoj ulozi i dalje iznimno podzastupljeni, žene su rijetko nositeljice i pokretačice radnje te manjkaju kvalitetno razrađeni odnosi koje bi žene imale s drugim ženskim likovima. I naravno, njihovo tijelo još je uvijek prečesto erotizirano te objekt muške žudnje i zurenja. Kako bi se takva stereotipna slika junakinja u akcijskom filmu promijenila, smatramo da postoji potreba za osmišljavanjem složenijih protagonistica koje se neće odreći vlastite ženstvenosti nauštrb snage i autonomnosti te koje će biti uzori novim generacijama rodno osviještenih djevojaka i mladića.

\section{Irena Sever Globan* - Ana Kral;*** \\ Action film heroines at the beginning of the new millennium}

\section{Summary}

Contemporary media are one of the factors that shape personal and social identity as well as social values on a global level, and in particular defining and shaping gender roles. They are often presented in the media through various stereotypes. While traditionally male characteristics are accentuated as more valuable, women in the media (especially the fiction ones) are reduced to the object of male desire. The article is therefore trying to find out whether there have been any changes in the last decade given the (non)stereotypical representation of film heroes and heroines of the action genre in Hollywood blockbusters. Using the method of content analysis, we have analysed 86 protagonists and major characters in the ten most watched films according to »Yearly Box Office « between 2007 and 2016. It was concluded that gender stereotypes are still present in action film successes, especially given the mall presence of female major characters and erotization and objectification of the female body.

Key words: media, gender roles, stereotypes, action films, film heroes.

(na engl. prev. Marko Globan)

* Irena Sever Globan, PhD, Assist. Prof., Department of Communication Studies, Catholic University of Croatia; Address: Ilica 242, HR-10000 Zagreb, Croatia; E-mail: irena.sever@ unicath.hr.

*** Ana Kralj, mag. comm, associate at RTL television; Address: Krapinska 45, HR-10000 Zagreb; E-mail: ana_kralj92@yahoo.com. 